\title{
Efficiency analysis of photovoltaic systems
}

\author{
Ewa Golisz*, Krzysztof Korpysz, Olga Rutkowska, Szymon Głowacki and Andrzej Bryś \\ Warsaw University of Life Sciences, Faculty of Production Engineering, Nowoursynowska 166, \\ 02-787 Warsaw, Poland
}

\begin{abstract}
The goal of the study was to analyse the efficiency of two existing photovoltaic micro-installations with the power of approx. 40 $\mathrm{kWp}$. The main factor differing the two installations being analysed was the arrangement of modules in relation to the sides of the world, one is south-west and the other is east-west. The total yield of electrical energy in 2017 from the south-west installation was higher and amounted to 34980 $\mathrm{kWh}$. For the east-west installation the amount of energy generated was equal to $31180 \mathrm{kWh} .4$ methods of forecasting electrical energy yield were discussed. Simple computational method proved to be the best method for both installations.
\end{abstract}

Keywords: photovoltaic systems, efficiency, renewable energy

\section{Introduction}

Development of civilization is directly related to the increasing demand for electrical and heat energy. In the era of innovation and continuous industrial development, creating energy industry linked to environment protection and the necessity of a new look at efficiency in industry is an extremely important task. Together with the increased demand for energy and the necessity to take care of the environment, large potential of renewable resources of energy including dynamically developing sector of innovative technologies such as photovoltaic cells, heat pumps, solar collectors and electric cars has been noticed [1].

In Poland, the main raw material for production of both thermal energy and electrical energy is coal. Renewable resources of energy (RRE) are perfect alternative to traditional non-renewable resources of energy. Their reserves are infinite, as they replenish naturally. Moreover, in comparison with traditional resources of energy, they are environmentally friendly. In Poland, renewable resources of energy covered $11.3 \%$ of demand for energy in 2016, and $10.9 \%$ in 2017 [2]. The main advantage of renewable resources of energy is no or very low (e.g. for biofuels, biogas) emission of greenhouse gasses [3]. The potential of RRE is extremely important considering the present rate of technological development. In Poland, the estimated share of RRE in the total primary energy used amounts to $46 \%$ (technical potential), and RRE share in final energy for 2020 is estimated at $22 \%$ (market potential) [4].

Solar radiation is one source of renewable energy. Its share in RRE in Poland amounted to only $0.58 \%$ (in 2016), while in the EU countries the share was equal to $6 \%$ (in 2015) [5].

\footnotetext{
*Corresponding author: ewa_golisz@sggw.pl
} 
The maximum power of solar energy reaching the earth is equal to $1366.1 \mathrm{~W} / \mathrm{m}^{2}$ [6], and the average solar irradiance ranges from approx. $100 \mathrm{~W} / \mathrm{m} 2$ to $300 \mathrm{~W} / \mathrm{m} 2$. The total energy that reaches the earth during the whole year ranges from $600 \mathrm{kWh} /\left(\mathrm{m}^{2} /\right.$ year $)$ in the Scandinavian countries to over $2500 \mathrm{kWh} / \mathrm{m}^{2} /$ year in central Africa [7]. In Poland, it amounts to approx. $1100 \mathrm{kWh} /\left(\mathrm{m}^{2} /\right.$ year $)$ [8]. Solar energy may be used in two ways, to produce electrical energy using photovoltaic cells and to produce heat using solar collectors [9-12].

Poland has good conditions for use of solar energy for energy production. Insolation, i.e. the sum of irradiation at a given area in given time, is similar on the territory of Poland. The annual density of solar radiation on a horizontal surface ranges within 950-1250 $\mathrm{kWh} / \mathrm{m} 2$. Insolation during the winter is 7 times lower than during the summer, with the peak yield of energy amounting to $150 \mathrm{kWh} / \mathrm{m}^{2}$ falling on June and July. The value of insolation in December is equal to $25 \mathrm{kWh} / \mathrm{m}^{2}$. Photovoltaic installations for electrical energy generation are becoming popular in Poland. These systems are being increasingly used for both housing and commercial purposes.

Photovoltaic modules (panels) are semiconductor elements, in which solar radiation energy is converted into electrical energy. The process occurs as a result of a photovoltaic effect involving formation of electromotive force at the connector of two semiconductors [13]. The energy generated in photovoltaic modules is in the form of DC (direct current). Each photovoltaic panel consists of photovoltaic cells connected in series. One pv module usually consists of $36-72$ photovoltaic cells [14].

The goal of the present study is to analyse the efficiency of two photovoltaic microinstallations with the power of approx. $40 \mathrm{kWp}$ based on their real production of electrical energy, and to compare the methods for forecasting production of electrical energy by pv installation. The criterion of selection of the forecasting methods was their popularity, availability and diversification.

\section{Methodology}

\subsection{Forecasting of electrical power from photovoltaic installations}

The study forecasts the yield of energy by four methods: two computational methods (complex and simple), a program used to design photovoltaic installations (PVSOL), and an internet calculator (PVGIS).

The complex computational method is based on perennial data published at the Ministry of Investment and Economic Development [15].

The number of daily hours in respective months was calculated for both meteorological stations from the formula:

$$
\begin{gathered}
L=\frac{a \cos [(-\tan (Q \cdot \pi / 180)) \cdot(\tan (N \cdot \pi / 180))]}{7.5 \cdot \pi / 180} \\
Q=-23.45 \cdot \cos [(2 \cdot \pi / 360) \cdot(D+10)]
\end{gathered}
$$

where: L-number of daily hours in a given month $[\mathrm{h}]$

$\mathrm{D}$-successive day of the year ;

$\mathrm{N}$ - latitude;

Q - solar declination angle, calculated for each day of the year

The forecast yield of electrical energy $\mathrm{Er}[\mathrm{kWh}]$ for each installation was calculated based on formula: 


$$
E_{r}=\frac{L \cdot I_{s r}}{S T C} \cdot E_{p}
$$

where: Isr-average solar irradiance for a given months $\left[\mathrm{kW} / \mathrm{m}^{2}\right]$

$\mathrm{E}_{\mathrm{p}}$-power of the powerplant $[\mathrm{kWp}]$

STC -solar irradiance in laboratory conditions (at which photovoltaic panels are tested) $=1[\mathrm{~kW} / \mathrm{m} 2]$.

The second computational method, called a simple method involves using data related to insolation of a given horizontal surface, read from maps of insolation or downloaded from the Ministry of Infrastructure and Development website, where accurate results for each Meteorological Station are published. The forecast yield of electrical energy was calculated from the formula [16]:

$$
E_{r}=\frac{\operatorname{Ins} \cdot C C \cdot E_{p} \cdot W W}{S T C}
$$

where: Ins - insolation on a horizontal surface $-\left[\mathrm{kWh} / \mathrm{m}^{2}\right]$

CC - correlation coefficient - coefficient that allows to calculate data about insolation on a sloped surface of photovoltaic modules based on data about insolation read from the map, which are for horizontal surface [-]

WW - performance coefficient, a coefficient that accounts for the level of losses at the photovoltaic installation including: losses at wires, inverter's losses, losses at modules due to temperature, losses due to work at low solar irradiance, losses due to shading, dirt, losses resulting from current mismatch in modules and losses at shunt diodes.

The third method of yield energy estimation uses PVSOL program developed by a German company Valentin Software. It is a professional program used by designers of photovoltaic systems in Poland and all over the world. It allows designers to visualize and design roof and ground installations. It may also be used to forecast electrical power yield from a photovoltaic system taking climatic data and shading of a given object into account [17].

The last method for forecasting energy was PVGIS (Photovoltaics Geographical Information System) program. It is a web-based program used to forecast electrical power yield from a photovoltaic system. This program allows the user to indicate the location of the $\mathrm{pv}$ installation with great accuracy, and uses insolation maps from its own database [18].

\section{Technical description of the installation}

\section{1 Characterization and location of the objects being analysed}

The subject of the analysis were two existing photovoltaic installations with the power of approx. $40 \mathrm{~kW}$ each, located in warmińsko-mazurskie province, about $80 \mathrm{~km}$ from each other. Both installations were installed in December 2016.

The first of the installations (further referred to as: Object 1, south-west installation) located in Myślęta, is installed on the roof of the outbuilding. Two sided roof is facing south-west and north-east direction. The roof slope is equal 30 degrees. The photovoltaic system is installed on the roof slope facing south-west (diversion from the south is equal $25^{\circ}$ ) and consists of 156 photovoltaic panels with the power of $255 \mathrm{Wp}$ each. The installed 
power of the whole system is equal $39.78 \mathrm{kWp}$ and the installation covers the area of $156 \mathrm{x}$ $1.7=265.2 \mathrm{~m} 2$.

The second of the examined installation (further referred to as: Object 2, west-east installation), located in Wyrandy, is installed on the roof of the piggery. The two sided roof is facing east and south directions, with the diversion of the eastern part to the north being equal to $24^{\circ}$. The roof slope is equal to 20 degrees. The system is installed on both roof slopes and consists of 152 photovoltaic modules with the power of $260 \mathrm{Wp}$ each. The power of the system is equal $39.52 \mathrm{kWp}$, and the installation covers the area of $152 \times 1.7=$ $258.4 \mathrm{~m} 2$. Both systems use polycrystalline modules manufactured by AEG (a German company). The main factor differing the two installations is the arrangement of the modules in relation to the sides of the world.

\subsection{Real electricity production in two pv installations}

Tables 1 and 2 show data for real monthly yield of electrical energy made available by the owners of the two described installations. The average, minimum and maximum daily yields of electrical energy were also calculated.

Table 1. Annual production of electrical energy in Object 1

\begin{tabular}{|l|c|c|c|c|}
\hline Month & $\begin{array}{c}\text { Total monthly } \\
\text { yield }[\mathbf{k W h}]\end{array}$ & $\begin{array}{c}\text { Average daily } \\
\text { yield }[\mathbf{k W h}]\end{array}$ & $\begin{array}{c}\text { Minimum daily } \\
\text { yield }[\mathbf{k W h}]\end{array}$ & $\begin{array}{c}\text { Maximum daily } \\
\text { yield }[\mathbf{k W h}]\end{array}$ \\
\hline January & 720 & 23.12 & 1.05 & 86.75 \\
\hline February & 1040 & 37.03 & 7.03 & 136.26 \\
\hline March & 2770 & 89.44 & 18.14 & 215.15 \\
\hline April & 4120 & 137.33 & 36.06 & 236.07 \\
\hline May & 6040 & 194.89 & 36.45 & 271.29 \\
\hline June & 4830 & 160.98 & 2.88 & 266.97 \\
\hline July & 5060 & 163.17 & 54.19 & 249.72 \\
\hline August & 5080 & 163.97 & 42.20 & 245.93 \\
\hline September & 2710 & 90.39 & 20.87 & 178.26 \\
\hline October & 1570 & 50.57 & 8.93 & 179.12 \\
\hline November & 590 & 19.81 & 0.51 & 81.57 \\
\hline December & 450 & 14.25 & 2.87 & 65.85 \\
\hline
\end{tabular}

The total annual production of electrical energy in Object 1 amounted to $34980 \mathrm{kWh}$. It may be observed based on the data presented in Tables 1 and 2 above that May is the best month for both installations taking the total monthly yield into consideration (6040 kWh), and leads as regards the average and maximum daily production. The least productive month is December, with the total yield being only $450 \mathrm{kWh}$.

Table 2. Annual production of electrical energy in Object 2

\begin{tabular}{|l|c|c|c|c|}
\hline Month & $\begin{array}{c}\text { Total monthly } \\
\text { yield }[\mathbf{k W h}]\end{array}$ & $\begin{array}{c}\text { Average daily } \\
\text { yield }[\mathbf{k W h}]\end{array}$ & $\begin{array}{c}\text { Minimum daily } \\
\text { yield }[\mathbf{k W h}]\end{array}$ & $\begin{array}{c}\text { Maximum daily } \\
\text { yield }[\mathbf{k W h}]\end{array}$ \\
\hline January & 480 & 15.47 & 0.84 & 58.23 \\
\hline February & 820 & 28.63 & 2.66 & 86.75 \\
\hline
\end{tabular}




\begin{tabular}{|l|c|c|c|c|}
\hline March & 2500 & 80.84 & 8.21 & 157.37 \\
\hline April & 3560 & 118.57 & 31.91 & 242.86 \\
\hline May & 5780 & 186.32 & 70.55 & 260.76 \\
\hline June & 4620 & 154.05 & 34.20 & 243.38 \\
\hline July & 4930 & 159.10 & 41.43 & 229.12 \\
\hline August & 4480 & 144.46 & 39.08 & 215.13 \\
\hline September & 2130 & 71.02 & 17.06 & 128.27 \\
\hline October & 1110 & 35.68 & 3.52 & 115.47 \\
\hline November & 510 & 17.18 & 2.16 & 48.52 \\
\hline December & 260 & 8.27 & 1.36 & 27.87 \\
\hline
\end{tabular}

The total annual production of electrical energy in Object 2 amounted to $31180 \mathrm{kWh}$. As for the 1st installation, the highest yields of electrical energy were recorded in May $(5789 \mathrm{kWh})$, and the smallest in December $(260 \mathrm{kWh})$.

The yield of energy in May was over 13-fold (Object 1) i 22-fold (Object 2) higher than in December. Fig. 1 presents a comparison of yields of electrical energy of the two compared photovoltaic systems during one year.

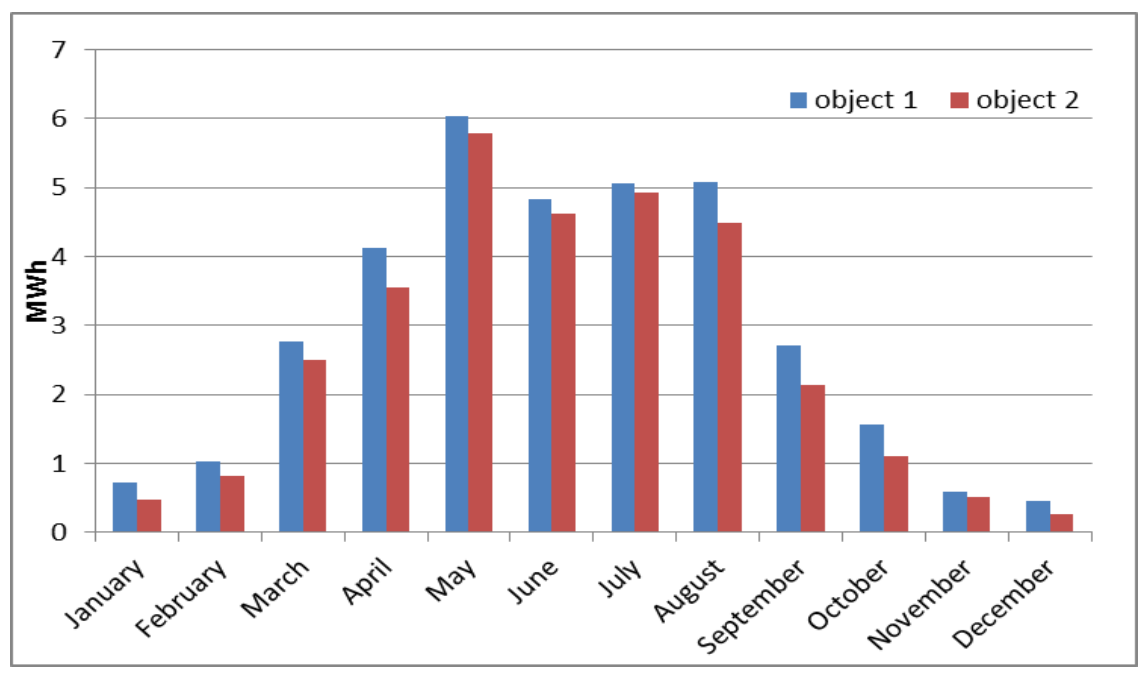

Fig. 1. A comparison of monthly yields of electrical energy in the installations being examined

By comparing the two installations, it may be observed that higher yields of energy for each month of 2017 were obtained in Object 1, i.e. the south-west installation.

Table 3 presents a comparison of unit yields of electrical energy from $1 \mathrm{kWp}$ of installed power of the two installations.

Table 3. Unit yield of electrical energy in Object 1 and 2

\begin{tabular}{|c|c|c|c|c|}
\hline & \multicolumn{2}{|c|}{ OBJECT 1 -south-west installation } & \multicolumn{2}{c|}{ OBJECT 2 east-west installation } \\
\hline Month & $\begin{array}{c}\text { Total yield } \\
{[\mathrm{kWh}]}\end{array}$ & $\begin{array}{c}\text { Unit yield from } 1 \mathrm{kWh} \\
{[\mathrm{kWh} / \mathrm{kWp}]}\end{array}$ & $\begin{array}{c}\text { Total yield } \\
{[\mathrm{MWh}]}\end{array}$ & $\begin{array}{c}\text { Unit yield from } 1 \mathrm{kWh} \\
{[\mathrm{kWh} / \mathrm{kWp}]}\end{array}$ \\
\hline January & 720 & 18.10 & 480 & 12.15 \\
\hline
\end{tabular}




\begin{tabular}{|l|c|c|c|c|}
\hline February & 1040 & 26.14 & 820 & 20.75 \\
\hline March & 2770 & 69.63 & 2500 & 63.26 \\
\hline April & 4120 & 103.57 & 3560 & 90.08 \\
\hline May & 6040 & 151.84 & 5780 & 146.26 \\
\hline June & 4830 & 121.42 & 4620 & 116.90 \\
\hline July & 5060 & 127.20 & 4930 & 124.75 \\
\hline August & 5080 & 127.70 & 4480 & 113.36 \\
\hline September & 2710 & 68.12 & 2130 & 53.90 \\
\hline October & 1570 & 39.47 & 1110 & 28.09 \\
\hline November & 590 & 14.83 & 510 & 12.90 \\
\hline December & 450 & 11.31 & 260 & 6.58 \\
\hline
\end{tabular}

In the south-west installation, the monthly yield of electrical energy ranges from $11.31 \mathrm{kWh} / \mathrm{kWp}$ to $151.84 \mathrm{kWh} / \mathrm{kWp}$ in May. The annual yield of electrical energy from 1 $\mathrm{kWp}$ amounts to $879 \mathrm{kWh} / \mathrm{kWp}$. In object 2 (east and south installation) the annual production amounts to $789 \mathrm{kWh} / \mathrm{kWp}$, which is equal to $90 \%$ of energy produced in Object 1. Monthly yields of electrical energy in the east and west installation range from 6.58 to $146.26 \mathrm{kWh} / \mathrm{kWp}$. The annual difference in the production of electrical energy between the south-west installation and the east-west installation is equal approx. 10\%. It may also be observed that from March to August, approx. $80 \%$ of annual amount of energy is produced in the examined pv installations.

\section{Results and discussion}

The basis of the analyses was real production of electrical energy obtained during the first year of operation of the two installations. Based on them, it was assessed, which of the installations being analysed, was more efficient both in economic and energy-related terms. The data were then used to select the optimum method of forecasting the production of electrical energy, i.e. the method which gave the results closest to the real production of electricity.

The next step of work, after the analyses real production of electrical energy, was simulation of electrical energy yield from the photovoltaic installations performed using different methods.

\subsection{Simulation of yield of electrical energy from the photovoltaic installations}

First was forecast of electrical energy production using the complex computational method. Based on full 30-year measurement series at the meteorological station in Mława (for Object 1) and in Olsztyn (for Object 2), a typical meteorological year was established. Data for insolation on south-western surface tilted at the angle of $30^{\circ}$, eastern tilted at the angle of $30^{\circ}$ and western tilted at the angle of $30^{\circ}$ were used to perform the calculations [19]. Then, the number of daily hours in respective months for both meteorological stations was calculated from formula 1 . Annual production of electrical energy calculated from equation 3 for Object 1 amounted to $35766 \mathrm{kWh}$. The difference between the real production of electrical energy and the energy forecast from the formula amounted to $786 \mathrm{kWh}$. It means that in reality, the photovoltaic installation installed on Object 1 produced $2.3 \%$ less energy in comparison with the forecast amount of energy. Forecast yield of electrical energy in Object 2, calculated from formula 3 amounted to $33630 \mathrm{kWh} /$ year. In comparison with the annual yields, it is $7.9 \%(2450 \mathrm{kWh})$ higher.

The second method was forecast of electrical energy based on the simple calculation method. In order to calculate the field of energy using the second method (formula 4), data 
presented in table 4 were used. In the case of south-east installation, annual electrical energy production amounted to $34706 \mathrm{kWh}$. The difference between the real and the forecast yield of electrical energy in Object 1 is minimal and is equal to as little as $0.8 \%$. In reality, the installation produced $274 \mathrm{kWh}$ more electrical energy than in the forecast. For the second installation, the annual forecast electrical power amounted to $30450 \mathrm{kWh}$. The difference between the real and the forecast yield of electrical power in Object 2 is greater than in Object 1 and is equal $2.3 \%$. In this case, the installation also produced more energy in reality than in the presented forecast.

Table 4. Data for forecasting electrical energy using simple computational method

\begin{tabular}{|c|c|c|}
\hline Parameter & Object 1 & Object 2 \\
\hline Ins.[kWh/m2] & 867.5 & 883.4 \\
\hline CC[-] & 1.13 & 0.98 \\
\hline Power [kWp] & 39.78 & 39.52 \\
\hline ww [-] & 0.89 & 0.89 \\
\hline STG [kW/m2] & 1 & 1 \\
\hline
\end{tabular}

Then, the electrical energy production was forecasted using the PVSol program. In order to forecast the yield of energy using PVSol program, the following parameters were input: data related to the module, producer, number of modules, generator power, inclination, orientation, type of installation. The forecast yields of electrical energy calculated by the program amounted to $40201 \mathrm{kWh} /$ year for Object 1 and $32125 \mathrm{kWh} /$ year for Object 2. In both cases, in comparison with the real yields, they are higher that the real production of electrical energy; by $14.9 \%$ for Object 1 and $3 \%$ for Object 2 . The difference between the real and the forecast production is equal to 5221 and $945 \mathrm{kWh} / \mathrm{year}$, respectively.

The final method was the forecast of electricity production using the PVGIS program. In order to perform a forecast of electrical energy production from pv systems installed on Object 1 and Object 2 using PVGIS program, the following data were input: location of the Objects based on Google maps; pv panels technology; power of the system; loses of the system; inclination angle of panels, azimuth angle. According to computations performed by PVGIS program, the annual production of electrical energy for Object 1 amounted to $39300 \mathrm{kWh} /$ year for the input parameters. In comparison with the real annual production of electrical energy, the estimated value is almost 10\% (3 $534 \mathrm{kWh})$ higher. According to computations performed by PVGIS program, the annual production of electrical energy for Object 2 for the input parameters amounted to $33600 \mathrm{kWh} /$ year. In comparison with the real annual production of electrical energy in a given object it is $7.8 \%$ more $(2420 \mathrm{kWh})$.

Table 5 presents values of real production of electrical energy, and the results of respective forecasts performed using 4 different methods and the percentage values of errors, compared with the real production of electrical energy in the examined systems. Based on the east difference between the forecast and the real production of electrical energy, an optimum method of forecasting field of electrical energy may be indicated.

Table 5. Forecast energy production by method

\begin{tabular}{|l|c|c|c|c|}
\hline & \multicolumn{2}{|c|}{ Object 1South-west installation } & \multicolumn{2}{|c|}{ Object 2East-west installation } \\
\hline $\begin{array}{l}\text { Real production of } \\
\text { electrical energy }\end{array}$ & \multicolumn{2}{|c|}{$34980 \mathrm{kWh} /$ year } & \multicolumn{2}{|c|}{$31180 \mathrm{kWh} /$ year } \\
\hline $\begin{array}{l}\text { Method of forecasting } \\
\text { electrical energy } \\
\text { production }\end{array}$ & $\begin{array}{c}\text { Electrical energy } \\
\text { production } \\
{[\mathrm{kWh} / \text { year] }}\end{array}$ & $\begin{array}{c}\text { Forecast } \\
\text { error [\%] }\end{array}$ & $\begin{array}{c}\text { Electrical energy } \\
\text { production } \\
{[\mathrm{kWh} / \text { year] }}\end{array}$ & $\begin{array}{c}\text { Forecast } \\
\text { error [\%] }\end{array}$ \\
\hline $\begin{array}{l}\text { 1. complex computational } \\
\text { method }\end{array}$ & 35766 & +2.3 & 33630 & +7.9 \\
\hline
\end{tabular}




\begin{tabular}{|l|c|c|c|c|}
\hline $\begin{array}{l}\text { 2. simple computational } \\
\text { method }\end{array}$ & 34706 & -0.8 & 30450 & -2.3 \\
\hline PVSOL program & 40201 & +14.9 & 32125 & +3.0 \\
\hline PVGIS program & 39300 & +12.4 & 33600 & +7.8 \\
\hline
\end{tabular}

Out of the four analysed methods of forecasting electrical energy production for both investigated photovoltaic installations, the best method proved to be the second computational method (simple). The forecast performed using this method for Object 1 differed by only $0.8 \%$ from the real production of electrical energy, and for Object 2 - by $2.3 \%$. In the case of the south-west installation (Object 2), the forecast performed using PVSOL program has a small forecast error equal $3.0 \%$.

Based on the computed percentage forecast error for both installations, it may be concluded that the best forecasting methods of electrical energy production for south-west installation are computational methods as PVSOL and PVGIS programs overestimated the production by over $12 \%$. To forecast electrical energy production by the east-west installation, the second computational method (simple) and PVSOL program may be recommended.

\section{Conclusions}

Based on the real production of electrical energy in 2017, it was concluded that electrical efficiency of the south-west installation was higher than the east-west installation. Unit yield of electrical energy from the south-west installation was equal $879 \mathrm{kWh} / \mathrm{kWp} /$ year, while the yield from the east-west installation was equal $789 \mathrm{kWh} / \mathrm{kWp} / \mathrm{year}$. The difference between the production of electrical energy in the south-west installation and the east-west installation is equal $10 \%$. Production of electrical energy in the south-west installation and the east-west installation in spring and summer months (from March to August) is similar, the difference between them ranges from 2 to $13 \%$. It is in these 6 months that $80 \%$ of the annual electrical energy is produced.

Based on the comparison of the four methods of forecasting electrical energy production from pv installation, it was concluded that the best method (in both cases) was the simple computational method. The difference between the forecast and the real production was equal to only $0.8 \%$, for the south-west installation, and it was equal to $2.3 \%$ for the east-west installation. Worse results were obtained using PGIS and PVSOL programs, for which the differences were as high as $14.9 \%$. However, the discrepancies between the results obtained by different forecasting methods may result from, i.a., using meteorological data from different sources, assumption of different coefficients of losses for the purpose of performing computations. Moreover, verification data were provided for only two installations and covered only one year. For more reliable selection of the best forecasting method, it is necessary to use data for a larger number of installations and longer verification period in order to eliminate weather randomness in a given year.

\section{References}

1. J. Popczyk. J, Energetyka rozproszona, Instytut Na Rzecz Ekorozwoju, Warszawa (2011)

2. Eurostat - Statistics Explained- Europa EU, (2018)

3. Ministerstwo Gospodarki: Polityka energetyczna Polski do 2030 roku. Załącznik 26 do uchwały nr 202/2009 Rady Ministrów Z 10 listopada 2009 r., Warszawa (2009).

4. Alternatywna Polityka Energetyczna Polski do roku 2030, Instytut Na Rzecz Ekorozwoju Warszawa (2009)

5. Główny Urząd Statystyczny (2017) 
6. N. Scafetta, R. Willson, ACRIM total solar irradiance satellite composite validation versus TSI proxy models. „Astrophysics and Space Science”. 350 (2), pp. 421-442, DOI: 10.1007/s10509013-1775-9 (2014)

7. Annual Solar Irradiance, Intermittency and Annual Variations. Green Rhino Energy, last accessed 2018/10/10

8. Z. Kusto, Wykorzystanie energii słonecznej, Wykorzystanie energii słonecznej. Instalacje słonecznego ogrzewania. Część 1, Politechnika Gdańska.

9. International Energy Agency (IEA. Renewables for Power Generation - Status and Prospects. IEA. Paryż (2003).

10. International Energy Agency (IEA). Organisation for Economic Co-operation and Development (OECD) i Nuclear Energy Agency (NEA). Projected Costs of Generating Electricity. OECD/IEA. Paryż (2005).

11. R. Szramka, A.W. Różycki, Perspektywy dla małych elektrowni wodnych. Biuletyn URE 4, (1999).

12. United Nations Development Programme (UNDP), United Nations Department of Economic and Social Affairs (UN-DESA) i World Energy Council (WEC). World Energy Assessment (WEA): Energy and the Challenge of Sustainability. UNDP. Nowy Jork (2000)

13. A De Vos, Thermodynamics of Solar Energy Conversion, Wiley-Vch Verlag GmbH \& Co, Weinheim, Germany (2008)

14. J.C. Sabonnadiere, Renewable Energy Technologies, John Wiley\&Sons, Inc., U.S.A. (2009)

15. Inwestycje, https://www.gov.pl/web/inwestycje-rozwoj, last accessed 2018/11/12

16. B. Szymański. Instalacje fotowoltaiczne. Poradnik. Kraków (2018)

17. PVSOL, https://www.valentin-software.com/en/products/photovoltaics/57/pvsol-premium, last accessed 2019/01/21

18. PVGIS, https://photovoltaic-software.com/pv-softwares-calculators/online-free-photovoltaic software/pvgis, last accessed 2019/01/21

19. MIiR, https:// archiwum.miir.gov.pl/strony/zadania/budownictwo/charakterystyka-energetyczna -budynkow/dane-do-obliczen-energetycznych-budynkow-1/, last accessed 2018/10/21 